\title{
Welcome New Associate Editor Sanziana Roman of the USA to the World Journal of Surgery
}

\author{
Julie Ann Sosa ${ }^{1}$
}

Published online: 12 November 2019

(C) Société Internationale de Chirurgie 2019

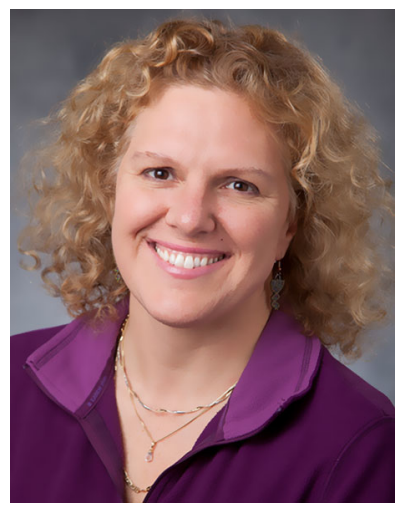

The World Journal of Surgery is pleased to announce that Sanziana Roman MD, FACS of San Francisco, CA, USA, has joined our team as an associate editor responsible for special features and innovation as well as general surgery.

Dr. Roman obtained her MD from Columbia University College of Physicians and Surgeons in New York. She completed her training in general surgery at Yale University, New Haven, CT, where she stayed on faculty for 13 years as the Chief of Endocrine Surgery and Director of the Endocrine Surgery Fellowship. She then became the

Chief of General Surgery at the Durham VAMC and the Vice Chief of Advanced GI and Oncologic Surgery at Duke University, Durham, North Carolina. She currently is a Professor of Surgery, the Dean's Diversity Leader, and the Director of Learning and Teaching of the Procedural Specialties at the University of California San Francisco (UCSF) School of Medicine. Dr. Roman is an accomplished endocrine surgeon, with special interests in minimally invasive surgical techniques. Her scholarly work has encompassed translational and health services research in the area of treatment effectiveness of endocrine cancer, long-term cancer survivorship, and the quality of surgical care. She has extensive experience in the use of administrative and cancer registry data to evaluate long-term consequences of cancer care for adults. She is the author of more than 200 peer-reviewed publications, numerous chapters, and a book.

Dr. Roman was born in Romania and raised in Transylvania, immigrating to the USA as a teenager. Prior to embarking on her medical career, she was a professional opera singer.

Publisher's Note Springer Nature remains neutral with regard to jurisdictional claims in published maps and institutional affiliations.

Julie Ann Sosa

julie.sosa@ucsf.edu

1 University of California San Francisco, San Francisco, USA 